\title{
Sinugibberosides A-E, new terpenoids with cyclic peroxyhemiketal from the soft coral Sinularia gibberosa
}

\author{
Shin-Pin Chen, ${ }^{\mathrm{a}}$ Atallah F. Ahmed, ${ }^{\mathrm{a} b}$ Chang-Feng Dai, ${ }^{\mathrm{c}}$ Chung-Kuang Lu, ${ }^{\mathrm{d}}$ \\ Wan-Ping $\mathrm{Hu},{ }^{\mathrm{e}}$ Jeh-Jeng Wang ${ }^{\mathrm{f}}$ and Jyh-Horng Sheu ${ }^{\mathrm{a}, *}$ \\ ${ }^{a}$ Department of Marine Biotechnology and Resources, National Sun Yat-Sen University, Kaohsiung 804, Taiwan \\ ${ }^{\mathrm{b}}$ Department of Pharmacognosy, Faculty of Pharmacy, Mansoura University, Mansoura 35516, Egypt \\ ${ }^{\mathrm{c}}$ Institute of Oceanography, National Taiwan University, Taipei 106, Taiwan \\ ${ }^{\mathrm{d}}$ National Museum of Marine Biology and Aquarium, Checheng, Pingtung 944, Taiwan \\ ${ }^{\mathrm{e}}$ Faculty of Biotechnology, Kaohsiung Medical University, Kaohsiung 807, Taiwan \\ ${ }^{\mathrm{f}}$ Faculty of Medicinal and Applied Chemistry, Kaohsiung Medical University, Kaohsiung 807, Taiwan
}

Received 27 March 2006; revised 27 April 2006; accepted 28 April 2006

Available online 23 May 2006

\begin{abstract}
The organic extract of the soft coral Sinularia gibberosa, collected from the northern Taiwan, has been investigated and resulted in the isolation of five new xeniaphyllane-type diterpenoids with a rare cyclic peroxyhemiketal (3,6-dihydro-1,2-dioxin-3-ol) moiety, sinugibberosides A-E (1-5). The structures of the new terpenoids, including their stereochemistries, were established on the basis of extensive spectroscopic analysis, including 1D and 2D NMR $\left({ }^{1} \mathrm{H}-{ }^{1} \mathrm{H}\right.$ COSY, HMQC, HMBC, and NOESY), and by comparison of their NMR data with those of related compounds. Metabolites 1-5 represent the first example of marine terpenoids possessing a cyclic peroxyhemiketal moiety. (C) 2006 Elsevier Ltd. All rights reserved.
\end{abstract}

\section{Introduction}

Soft corals belonging to genus Sinularia (Alcyoniidae), have been well recognized as a rich source of structurally unique and biologically active diterpenoids ${ }^{1}$ and norditerpenoids. ${ }^{1-3}$ During the course of our screening of bioactive metabolites from marine organisms, ${ }^{3-8}$ we have reported the isolation of xeniaphyllane-based diterpenoids and $\beta$-caryophyllanetype sesquiterpenoids from genus Sinularia. ${ }^{3}$ Moreover, a chemical investigation on a sample of Sinularia gibberosa Tixier-Durivault, collected from the southern Taiwanese waters near Kenting, had furnished a variety of cytotoxic steroids $^{9}$ along with guaiane- and germacrane-derived sesquiterpenoids. ${ }^{10}$ Recently, we reinvestigated the same organism, collected from the northern east coast of Taiwan, and found that the xeniaphyllane-type diterpenoids ${ }^{3,11,12}$ is also the terpenoidal constituents of this organism. Five new xeniaphyllane-derived diterpenoids with the rare 3,6-dihydro-1,2-dioxin-3-ol ${ }^{13}$ (cyclic peroxyhemiketal) subunit, sinugibberosides A-E (1-5), were isolated from the EtOAc extract of $S$. gibberosa. Their structures, including their stereochemistries, were elucidated on the basis of extensive

Keywords: Sinugibberosides A-E; Cyclic peroxyhemiketal; Xeniaphyllane; Sinularia gibberosa.

* Corresponding author. Tel.: +886 7 5252000x5030; fax: +886 75255020 ; e-mail: sheu@mail.nsysu.edu.tw spectroscopic (including 1D and 2D NMR) analysis and by comparison of their spectral data with those of the related compounds. Although polyketide-derived esters with cyclic peroxyketal moiety have been isolated from sponges of the genera Chondrilla ${ }^{14}$ and Xestospongia ${ }^{15}$ and a sesquiterpenoid with cyclic peroxyhemiketal subunit was afforded from two asteraceous herbs, ${ }^{16,17}$ Sinugibberosides A-E are reported herein as the first example of marine terpenoids possessing the rare 3,6-dihydro-1,2-dioxin-3-ol group (Fig. 1).
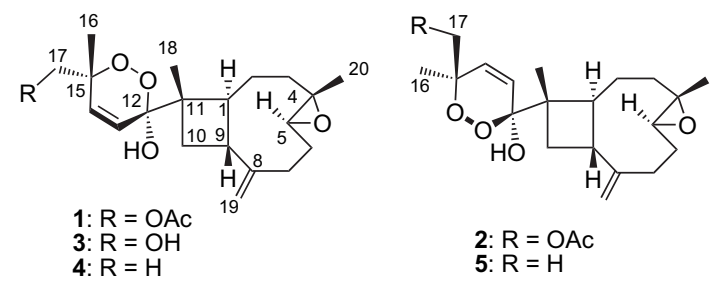

3: $\mathrm{R}=\mathrm{OH}$

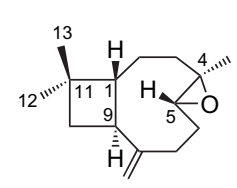

6

$$
\begin{aligned}
& \text { 2: } R=O A C \\
& \text { 5: } R=H
\end{aligned}
$$

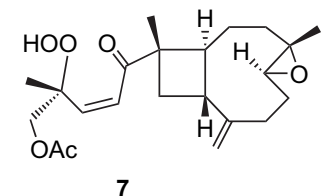

Figure 1. Structures of new metabolites 1-5, a known compound 6, and a hypothetical precursor 7 . 


\section{Results and discussion}

The minced bodies of $S$. gibberosa were exhaustively extracted with EtOAc and the concentrated extract was fractionated by column chromatography on silica gel using $n$-hexane and $n$-hexane-EtOAc mixture of increasing polarity. The eluted fractions were further purified by various chromatographic techniques including gel permeation and HPLC to afford 1-5 (see Section 3). All new metabolites were obtained as colorless oils and have been shown to exhibit a positive sign for optical rotations.

Sinugibberoside A (1) was found to possess a molecular formula $\mathrm{C}_{22} \mathrm{H}_{32} \mathrm{O}_{6}$ as established from its HRESIMS $(\mathrm{m} / \mathrm{z}$ 415.2093, $[\mathrm{M}+\mathrm{Na}]^{+}$), implying seven degrees of unsaturation. The IR spectrum indicated the presence of hydroxy $\left(\nu_{\max } 3400 \mathrm{~cm}^{-1}\right)$ and ester $\left(\nu_{\max } 1746 \mathrm{~cm}^{-1}\right)$ groups in the molecule. The ${ }^{1} \mathrm{H}$ NMR data (Table 1 ) revealed the presence of two upper field shifted methyls ( $\delta 1.13$ and 1.19 , each $3 \mathrm{H}, \mathrm{s})$, one trisubstituted epoxide $(\delta 2.95,1 \mathrm{H}$, dd, $J=10.5,4.5 \mathrm{~Hz}$ ), 1,1-disubstituted double bond $(\delta 4.88$ and 5.04, each $1 \mathrm{H}, \mathrm{s})$, and two ${ }^{1} \mathrm{H}-{ }^{1} \mathrm{H}$ COSY correlated ringjuncture methines $(\delta 2.80,1 \mathrm{H}, \mathrm{dd}, J=10.0,9.5 \mathrm{~Hz}$ and $2.63,1 \mathrm{H}, \mathrm{q}, J=9.5 \mathrm{~Hz}$ ), characteristic of an 4,5-epoxycaryophyllene (6) moiety ${ }^{3,11,12,18}$ in $\mathbf{1}$. This was further supported by the similar ${ }^{13} \mathrm{C}$ NMR data (Table 2) of C-2 to C-11 and C-18 to C-20 with those of related metabolites. $3,11,12$ Therefore, the substituent at C-11 of the molecule should require three degrees of unsaturation to comply with the MS data. This was satisfied by the presence of one acetoxyl $\left(\delta_{\mathrm{H}} 2.08,3 \mathrm{H}, \mathrm{s} ; \delta_{\mathrm{C}} 170.5, \mathrm{qC}\right.$ and $\left.20.7, \mathrm{CH}_{3}\right)$, one 1,2-disubstituted double bond $\left(\delta_{\mathrm{H}} 5.83\right.$ and 5.88 , each $1 \mathrm{H}, \mathrm{d}, J=$ $10.5 \mathrm{~Hz} ; \delta_{\mathrm{C}} 127.0$ and 130.5 , each $\mathrm{CH}$ ), and one additional ring. The latter was suggested to be a 3,6-dihydro-1,2dioxin-3-ol moiety on the basis of the chemical shifts of the two above-mentioned olefinic carbons and the oxycarbon signals appearing at $\delta 99.6$ and 78.9 (each $1 C, \mathrm{qC}){ }^{13,16}$
Also, the HMBC correlations found from $\mathrm{H}_{3}-18(\delta 1.13$, $3 \mathrm{H}, \mathrm{s})$ and a hydroxy proton $(\delta 3.29,1 \mathrm{H}$, br s) at the quaternary oxycarbon ( $\delta 99.6, \mathrm{qC}, \mathrm{C}-12)$ could assign the latter as the hemiketal carbon of the 3,6-dihydro-1,2-dioxin-3-ol group in 1. Moreover, the detailed analyses of the ${ }^{1} \mathrm{H}-{ }^{1} \mathrm{H}$ COSY and HMBC correlations (Fig. 2) established $\mathbf{1}$ as one of the 4,5-epoxyxeniaphyllane diterpenoids. ${ }^{3,11,12}$ The above correlations also revealed that the $\mathrm{C}-11$ linked side chain is 12,15-epidioxidized to form a cyclic hemiketal group with hydroxy and methyl $\left(\delta_{\mathrm{H}} 1.44,3 \mathrm{H}, \mathrm{s} ; \delta_{\mathrm{C}} 19.6\right.$, $\left.\mathrm{CH}_{3}\right)$ and acetoxymethyl $\left(\delta_{\mathrm{H}} 3.98\right.$ and 4.18 , each $1 \mathrm{H}, \mathrm{d}$, $J=12.0 \mathrm{~Hz} ; \delta_{\mathrm{C}} 66.4, \mathrm{CH}_{2}$ ) substituents at C-12 and C-15, respectively. Furthermore, the ion peak appeared in the MS spectrum at $m / z 205\left[\mathrm{M}-\mathrm{C}_{8} \mathrm{H}_{11} \mathrm{O}_{5}\right]^{+}$should be due to the cleavage of 1 , between $\mathrm{C}-11$ and $\mathrm{C}-12$ to afford the trisubstituted cyclic hemiketal moiety at $m / z, 187\left[\mathrm{C}_{8} \mathrm{H}_{11} \mathrm{O}_{5}\right]^{+}$.

The NOE interactions (Fig. 3) displayed by the two trans ring-fused methine protons $\mathrm{H}-1$ ( $\delta$ 2.80, dd, $J=10.0$, $9.5 \mathrm{~Hz})$ and $\mathrm{H}-9(\delta 2.63, \mathrm{q}, J=9.5 \mathrm{~Hz})$ with $\mathrm{H}-5(\delta 2.95$, $\mathrm{dd}, J=10.5,4.5 \mathrm{~Hz})$ and $\mathrm{H}_{3}-20(\delta 1.19$, s), respectively, revealed the $1 S^{*}, 4 S^{*}, 5 S^{*}, 9 R^{*}$ configuration in $\mathbf{1}$, as found in the related 4,5-epoxyxeniapyllenes previously isolated from Sinularia species by our group. ${ }^{3}$ The NOE correlations observed between $\mathrm{H}-9$ and $\mathrm{H}_{3}-18(\delta 1.13$, s) positioned the methyl group at $\mathrm{C}-11$ on the $\beta$-face of the molecule. This was further supported by the NOE correlations found between $\mathrm{H}-10 \beta(\delta 1.56, \mathrm{~m})$ and both $\mathrm{H}-9$ and $\mathrm{H}_{3}-18$. Thus, $\mathrm{C}-11$ is $S^{*}$ configured. Moreover, the olefinic H-13 showed NOE interactions with both $\mathrm{H}_{3}-18$ and $\mathrm{H}_{2}-10$ but not with $\mathrm{H}_{2}-2$, revealing that the 13,14 -double bond of the cyclic peroxyhemiketal moiety at $\mathrm{C}-11$ is placed in the position close to $\mathrm{C}-10$ and the peroxide is located near $\mathrm{C}-1$ of the $\beta$-caryophyllene moiety of $\mathbf{1}$, respectively. Therefore, the significant $\mathrm{NOE}$ interaction displayed between the $\beta$-oriented $\mathrm{H}_{3}-18$ and $\mathrm{H}_{3}-16$ established the $\beta$-orientation of the methyl at $\mathrm{C}-15$ and hence, the $\alpha$-orientation of the hydroxyl at C-12.

Table 1. ${ }^{1} \mathrm{H}$ NMR chemical shifts of compounds 1-5

\begin{tabular}{|c|c|c|c|c|c|}
\hline & $\mathbf{1}^{\mathrm{a}}$ & $2^{b}$ & $3^{\mathrm{c}}$ & $4^{c}$ & $5^{c}$ \\
\hline 1 & $2.80 \mathrm{dd}(10.0,9.5)^{\mathrm{d}}$ & $2.60 \mathrm{dd}(9.5,9.5)$ & $2.78 \mathrm{dd}(10.0,9.6)$ & $2.78 \mathrm{dd}(10.0,9.5)$ & $2.58 \mathrm{dd}(9.0,9.0)$ \\
\hline $2 \alpha$ & 1.77 ddd $(15.0,4.0,4.0)$ & 1.75 ddd $(15.0,4.8,3.3)$ & 1.77 ddd $(14.6,4.0,3.6)$ & 1.77 ddd $(14.4,3.6,3.6)$ & 1.78 ddd $(14.6,4.2,2.8)$ \\
\hline $2 \beta$ & $1.45 \mathrm{~m}$ & $1.52 \mathrm{~m}$ & $1.45 \mathrm{~m}$ & $1.45 \mathrm{~m}$ & $1.49 \mathrm{~m}$ \\
\hline $3 \alpha$ & 1.05 ddd $(12.5,12.5,3.0)$ & 1.02 ddd $(12.9,12.9,4.8)$ & 1.05 ddd $(13.0,13.0,5.2)$ & $1.06 \mathrm{~m}$ & 1.02 ddd $(12.6,12.6,4.2)$ \\
\hline $3 \beta$ & $2.06 \mathrm{~m}$ & $2.07 \mathrm{~m}$ & 2.04 ddd $(13.0,4.4,4.4)$ & 2.03 ddd $(12.0,3.6,3.6)$ & 2.06 ddd $(12.6,4.2,2.8)$ \\
\hline 5 & $2.95 \mathrm{dd}(10.5,4.5)$ & $2.93 \mathrm{dd}(10.5,4.0)$ & $2.96 \mathrm{dd}(10.5,4.0)$ & $2.95 \mathrm{dd}(10.5,4.0)$ & $2.92 \mathrm{dd}(10.5,4.0)$ \\
\hline $6 \alpha$ & 2.28 ddd $(16.0,8.0,4.5)$ & $2.27 \mathrm{~m}$ & 2.28 ddd $(16.4,7.2,4.0)$ & $2.27 \mathrm{~m}$ & $2.28 \mathrm{~m}$ \\
\hline $6 \beta$ & $1.33 \mathrm{~m}$ & $1.31 \mathrm{~m}$ & $1.31 \mathrm{~m}$ & $1.32 \mathrm{~m}$ & $1.31 \mathrm{~m}$ \\
\hline $7 \alpha$ & 2.40 ddd $(13.0,9.0,4.0)$ & 2.38 ddd $(12.6,8.0,4.0)$ & 2.40 ddd $(12.8,8.8,4.0)$ & 2.40 ddd $(12.8,9.2,4.0)$ & 2.38 ddd $(12.8,8.4,4.0)$ \\
\hline $7 \beta$ & $2.16 \mathrm{~m}$ & $2.17 \mathrm{~m}$ & 2.17 ddd $(12.8,7.2,4.0)$ & $2.17 \mathrm{~m}$ & 2.16 ddd $(12.8,6.0,4.0)$ \\
\hline 9 & $2.63 \mathrm{q}(9.5)$ & $2.62 \mathrm{q}(9.5)$ & $2.63 \mathrm{q}(9.6)$ & $2.62 \mathrm{q}(9.5)$ & $2.63 \mathrm{q}(9.0)$ \\
\hline $10 \alpha$ & $2.20 \mathrm{dd}(10.5,9.5)$ & $2.27 \mathrm{dd}(10.0,9.5)$ & 2.22 dd $(10.4,9.6)$ & 2.22 dd $(10.0,9.5)$ & 2.25 dd $(10.0,9.0)$ \\
\hline $10 \beta$ & $1.56 \mathrm{~m}$ & $1.52 \mathrm{~m}$ & $1.54 \mathrm{~m}$ & $1.55 \mathrm{~m}$ & $1.54 \mathrm{~m}$ \\
\hline 13 & $5.83 \mathrm{~d}(10.5)$ & $5.86 \mathrm{~d}(10.5)$ & $5.85 \mathrm{~d}(10.0)$ & $5.65 \mathrm{~d}(10.0)$ & $5.72 \mathrm{~d}(10.0)$ \\
\hline 14 & $5.88 \mathrm{~d}(10.5)$ & $5.93 \mathrm{~d}(10.5)$ & $5.95 \mathrm{~d}(10.0)$ & $5.93 \mathrm{~d}(10.0)$ & $5.95 \mathrm{~d}(10.0)$ \\
\hline 16 & $1.44 \mathrm{~s}, 3 \mathrm{H}$ & $1.26 \mathrm{~s}, 3 \mathrm{H}$ & $1.35 \mathrm{~s}, 3 \mathrm{H}$ & $1.40 \mathrm{~s}, 3 \mathrm{H}$ & $1.39 \mathrm{~s}, 3 \mathrm{H}$ \\
\hline 17 & $3.98 \mathrm{~d}(12.0), 4.18 \mathrm{~d}(12.0)$ & $4.12 \mathrm{~d}(11.7), 4.27 \mathrm{~d}(11.7)$ & $3.58 \mathrm{~d}(12.0), 3.63 \mathrm{~d}(12.0)$ & $1.23 \mathrm{~s}, 3 \mathrm{H}$ & $1.23 \mathrm{~s}, 3 \mathrm{H}$ \\
\hline 18 & $1.13 \mathrm{~s}, 3 \mathrm{H}$ & $1.15 \mathrm{~s}, 3 \mathrm{H}$ & $1.14 \mathrm{~s}, 3 \mathrm{H}$ & $1.13 \mathrm{~s}, 3 \mathrm{H}$ & $1.17 \mathrm{~s}, 3 \mathrm{H}$ \\
\hline 19 & $4.88 \mathrm{~s}, 5.04 \mathrm{~s}$ & $4.88 \mathrm{~s}, 5.04 \mathrm{~s}$ & $4.88 \mathrm{~s}, 5.04 \mathrm{~s}$ & $4.87 \mathrm{~s}, 5.04 \mathrm{~s}$ & $4.87 \mathrm{~s}, 5.04 \mathrm{~s}$ \\
\hline 20 & $1.19 \mathrm{~s}, 3 \mathrm{H}$ & $1.19 \mathrm{~s}, 3 \mathrm{H}$ & $1.19 \mathrm{~s}, 3 \mathrm{H}$ & $1.18 \mathrm{~s}, 3 \mathrm{H}$ & $1.19 \mathrm{~s}, 3 \mathrm{H}$ \\
\hline Ac & $2.08 \mathrm{~s}, 3 \mathrm{H}$ & $2.11 \mathrm{~s}, 3 \mathrm{H}$ & & & \\
\hline $12-\mathrm{OH}$ & 3.29 br s & $3.23 \mathrm{~s}$ & 3.50 br s & $3.15 \mathrm{~s}$ & $3.12 \mathrm{~s}$ \\
\hline
\end{tabular}

\footnotetext{
a Spectra recorded at $500 \mathrm{MHz}$ in $\mathrm{CDCl}_{3}$.

b Spectra recorded at $300 \mathrm{MHz}$ in $\mathrm{CDCl}_{3}$.

c Spectra recorded at $400 \mathrm{MHz}$ in $\mathrm{CDCl}_{3}$.

d The $J$ values are given in hertz in parentheses.
} 
Table $2 .{ }^{13} \mathrm{C}$ NMR chemical shifts of compounds $\mathbf{1}-\mathbf{5}$

\begin{tabular}{|c|c|c|c|c|c|}
\hline No. & $\mathbf{1}^{\mathrm{a}}$ & $2^{\mathrm{b}}$ & $3^{\mathrm{c}}$ & $4^{c}$ & $5^{\mathrm{c}}$ \\
\hline 1 & $-^{\mathrm{d}}$ & $43.2(\mathrm{CH})^{\mathrm{e}}$ & - & - & $43.0(\mathrm{CH})$ \\
\hline 2 & $28.3\left(\mathrm{CH}_{2}\right)$ & $28.6\left(\mathrm{CH}_{2}\right)$ & $28.5\left(\mathrm{CH}_{2}\right)$ & $28.7\left(\mathrm{CH}_{2}\right)$ & $28.8\left(\mathrm{CH}_{2}\right)$ \\
\hline 3 & $38.6\left(\mathrm{CH}_{2}\right)$ & $38.6\left(\mathrm{CH}_{2}\right)$ & $38.6\left(\mathrm{CH}_{2}\right)$ & $38.9\left(\mathrm{CH}_{2}\right)$ & $38.9\left(\mathrm{CH}_{2}\right)$ \\
\hline 4 & $59.8(\mathrm{qC})$ & $59.6(\mathrm{qC})$ & $59.8(\mathrm{qC})$ & $60.0(\mathrm{qC})$ & $59.9(\mathrm{qC})$ \\
\hline 5 & $63.9(\mathrm{CH})$ & $63.9(\mathrm{CH})$ & $63.9(\mathrm{CH})$ & $64.2(\mathrm{CH})$ & $64.1(\mathrm{CH})$ \\
\hline 6 & $30.2\left(\mathrm{CH}_{2}\right)$ & $30.1\left(\mathrm{CH}_{2}\right)$ & $30.2\left(\mathrm{CH}_{2}\right)$ & $30.5\left(\mathrm{CH}_{2}\right)$ & $30.4\left(\mathrm{CH}_{2}\right)$ \\
\hline 7 & $29.5\left(\mathrm{CH}_{2}\right)$ & $29.4\left(\mathrm{CH}_{2}\right)$ & $30.2\left(\mathrm{CH}_{2}\right)$ & $30.0\left(\mathrm{CH}_{2}\right)$ & $29.7\left(\mathrm{CH}_{2}\right)$ \\
\hline 8 & $151.6(\mathrm{gC})$ & $151.3(\mathrm{gC})$ & $151.6(\mathrm{qC})$ & $151.9(\mathrm{gC})$ & $151.7(\mathrm{qC})$ \\
\hline 9 & $47.6(\mathrm{CH})$ & $48.2(\mathrm{CH})$ & $47.7(\mathrm{CH})$ & $47.9(\mathrm{CH})$ & $48.4(\mathrm{CH})$ \\
\hline 10 & $33.2\left(\mathrm{CH}_{2}\right)$ & $31.9\left(\mathrm{CH}_{2}\right)$ & $33.2\left(\mathrm{CH}_{2}\right)$ & $33.4\left(\mathrm{CH}_{2}\right)$ & $32.4\left(\mathrm{CH}_{2}\right)$ \\
\hline 11 & $41.7(\mathrm{qC})$ & $41.5(\mathrm{qC})$ & $42.0(\mathrm{qC})$ & $42.1(\mathrm{qC})$ & $42.9(\mathrm{qC})$ \\
\hline 12 & $99.6(\mathrm{qC})$ & $99.2(\mathrm{qC})$ & $99.6(\mathrm{qC})$ & $99.6(\mathrm{qC})$ & $99.5(\mathrm{qC})$ \\
\hline 13 & $127.0(\mathrm{CH})$ & $127.2(\mathrm{CH})$ & $126.6(\mathrm{CH})$ & $124.3(\mathrm{CH})$ & $124.3(\mathrm{CH})$ \\
\hline 14 & $130.5(\mathrm{CH})$ & $131.3(\mathrm{CH})$ & $131.7(\mathrm{CH})$ & $135.7(\mathrm{CH})$ & $136.2(\mathrm{CH})$ \\
\hline 15 & 78.9 (qC) & 78.0 (qC) & $80.5(\mathrm{qC})$ & 77.4 (qC) & $77.2(\mathrm{qC})$ \\
\hline 16 & $19.6\left(\mathrm{CH}_{3}\right)$ & $19.8\left(\mathrm{CH}_{3}\right)$ & $19.3\left(\mathrm{CH}_{3}\right)$ & $24.4\left(\mathrm{CH}_{3}\right)$ & $24.3\left(\mathrm{CH}_{3}\right)$ \\
\hline 17 & $66.4\left(\mathrm{CH}_{2}\right)$ & $64.6\left(\mathrm{CH}_{2}\right)$ & $66.9\left(\mathrm{CH}_{2}\right)$ & $24.8\left(\mathrm{CH}_{3}\right)$ & $24.8\left(\mathrm{CH}_{3}\right)$ \\
\hline 18 & $15.7\left(\mathrm{CH}_{3}\right)$ & $15.6\left(\mathrm{CH}_{3}\right)$ & $15.8\left(\mathrm{CH}_{3}\right)$ & $16.0\left(\mathrm{CH}_{3}\right)$ & $15.6\left(\mathrm{CH}_{3}\right)$ \\
\hline 19 & $113.6\left(\mathrm{CH}_{2}\right)$ & $113.7\left(\mathrm{CH}_{2}\right)$ & $113.6\left(\mathrm{CH}_{2}\right)$ & $113.7\left(\mathrm{CH}_{2}\right)$ & $113.8\left(\mathrm{CH}_{2}\right)$ \\
\hline 20 & $17.1\left(\mathrm{CH}_{3}\right)$ & $17.1\left(\mathrm{CH}_{3}\right)$ & $17.1\left(\mathrm{CH}_{3}\right)$ & $17.4\left(\mathrm{CH}_{3}\right)$ & $17.3\left(\mathrm{CH}_{3}\right)$ \\
\hline Ac & $170.5(\mathrm{qC}), 20.7\left(\mathrm{CH}_{3}\right)$ & $170.7\left(\mathrm{CH}_{3}\right), 20.8\left(\mathrm{CH}_{3}\right)$ & & & \\
\hline
\end{tabular}

${ }^{\text {a }}$ Spectra recorded at $125 \mathrm{MHz}$ in $\mathrm{CDCl}_{3}$ at $25^{\circ} \mathrm{C}$.

b Spectra recorded at $75 \mathrm{MHz}$ in $\mathrm{CDCl}_{3}$ at $25^{\circ} \mathrm{C}$.

c Spectra recorded at $100 \mathrm{MHz}$ in $\mathrm{CDCl}_{3}$ at $25^{\circ} \mathrm{C}$.

d Methine carbon signal was not observable and no corresponding HMQC and HMBC correlations were found.

e Attached protons were determined by DEPT experiments. The values are given in parts per million lower field from TMS.

Furthermore, the molecular mechanics calculations was performed to study the conformational behavior of $\mathbf{1}$. The conformational analysis suggested the most stable conformation at $228.4 \mathrm{Kcal} / \mathrm{mol}$ as shown in Figure 4. It was found that the calculated distances between protons having key NOE correlations around $\mathrm{C}-12$ of the cyclic peroxyhemiketal moiety were ranging from 2.8 to $3.2 \AA$ as shown in Table 3. Based on the above findings, the structure of sinugibberoside $\mathrm{A}$ was fully established as $\left(1 S^{*}, 4 S^{*}, 5 S^{*}, 9 R^{*}, 11 S^{*}, 12 R^{*}, 15 R^{*}\right)$ 4,5-epoxy-12,15-epidioxy-17-acetoxy-xeniaphylla-8(19),13dien-12-ol.

Sinugibberoside B (2) was found to possess the same molecular formula $\mathrm{C}_{22} \mathrm{H}_{32} \mathrm{O}_{6}$ as that of $\mathbf{1}$ from the HRESIMS $(\mathrm{m} / \mathrm{z}$ $415.2093[\mathrm{M}]^{+}$) and NMR spectral data (Tables 1 and 2). The ${ }^{13} \mathrm{C}$ NMR data of $\mathbf{2}$ (Table 2) were found to be quite similar to those of $\mathbf{1}$. Therefore, $\mathbf{2}$ was suggested to be an isomer of $\mathbf{1}$. However, we observed the upper field shifts for C-10, $\mathrm{C}-15$, and $\mathrm{C}-17(\Delta \delta-1.3,-0.9$, and -1.8 , respectively)
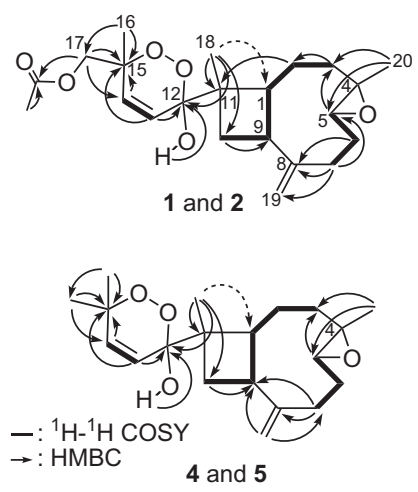

Figure 2. ${ }^{1} \mathrm{H}-{ }^{1} \mathrm{H}$ COSY and $\mathrm{HMBC}$ correlations for 1, 2, 4, and 5. Other HMBC correlation (dashed arrow) found for $\mathbf{2}$ and $\mathbf{5}$. and a lower field shift for C-9 $(\Delta \delta+0.6)$ of 2 relative to those of $\mathbf{1}$. Also, although the ${ }^{1} \mathrm{H}$ NMR data of $\mathbf{2}$ (Table 1) showed high similarity with those of $\mathbf{1}$, substantial differences for chemical shifts of $\mathrm{H}-1, \mathrm{H}_{3}-16$, and $\mathrm{H}-17(\Delta \delta-0.20$, -0.18 , and +0.14 , respectively) relative to those of 1 were
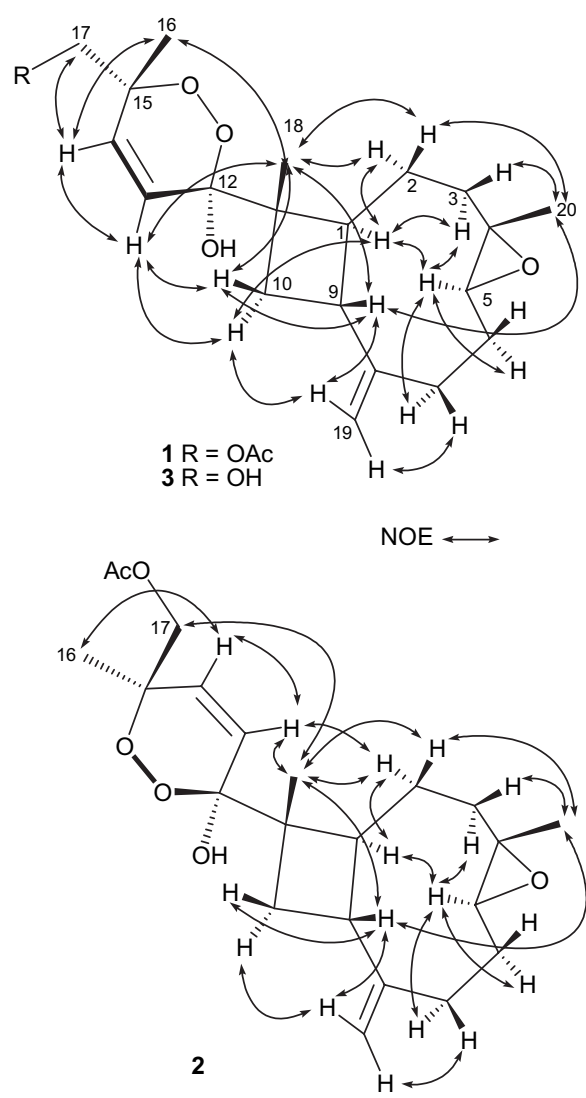

Figure 3. Observed NOESY correlations for 1-3. 

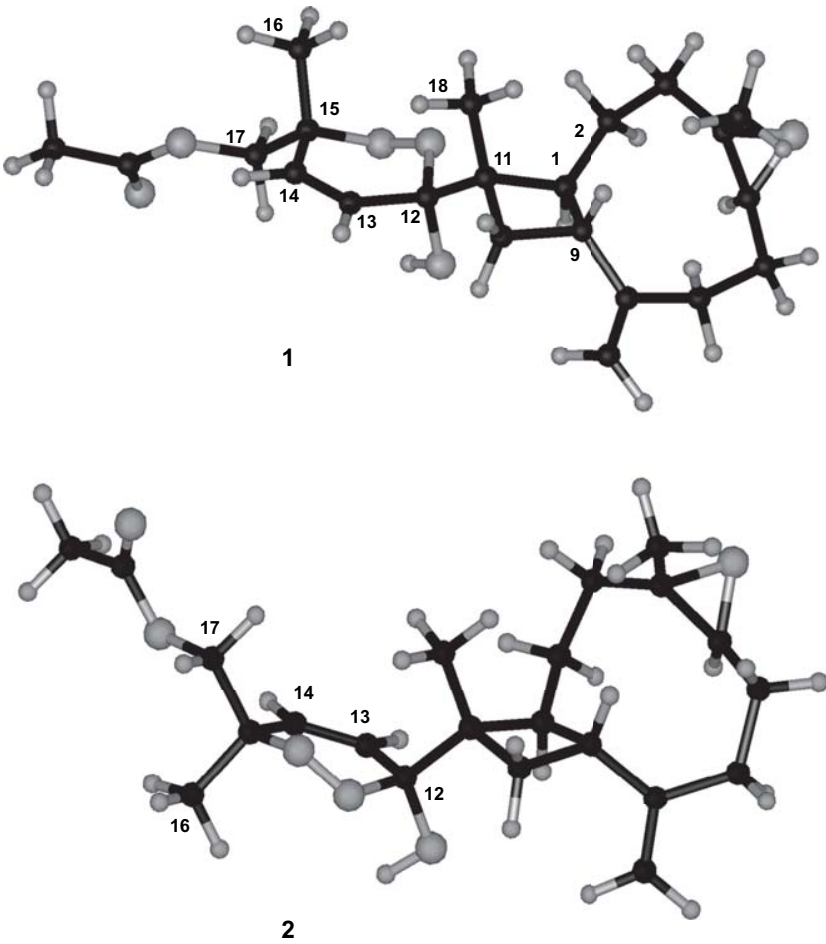

Figure 4. Stereo-view of $\mathbf{1}$ and $\mathbf{2}$ generated from computer modeling.

found. After the establishment of the planar structure of $\mathbf{2}$ by analysis of ${ }^{1} \mathrm{H}-{ }^{1} \mathrm{H}$ COSY and $\mathrm{HMBC}$ correlations (Fig. 2), we then carefully examined the NOESY correlations of $\mathbf{2}$ by comparison with those of $\mathbf{1}$ (Fig. 3). The NOESY spectrum of $\mathbf{2}$ exhibited similar NOE correlations as those found in $\mathbf{1}$, and led to the determination of the $S^{*}, S^{*}, S^{*}$, $R^{*}$, and $S^{*}$ configurations at C-1, C-4, C-5, C-9, and C- 11 , respectively. The NOE interactions found for the olefinic proton at $\mathrm{C}-13$ with both $\mathrm{H}_{3}-18(\delta 1.15, \mathrm{~s})$ and $\mathrm{H}-2 \alpha(\delta 1.75$, ddd, $J=15.0,4.8,3.3 \mathrm{~Hz}$ ), and $\mathrm{H}_{3}-18$ with $\mathrm{H}-9(\delta 2.62$, $\mathrm{q}, J=9.5 \mathrm{~Hz})$ and $\mathrm{H}-17(\delta 4.12, \mathrm{~d}, J=11.7 \mathrm{~Hz})$ further established the relative stereochemistry of $\mathbf{2}$ as shown in Figure 3 . On the basis of the above findings, compound $\mathbf{2}$ was identified as the 12-epimer of $\mathbf{1}$. Moreover, the molecular mechanics calculations suggested the most stable conformation at $232.3 \mathrm{Kcal} / \mathrm{mol}$ as shown in Figure 4. From this conformation, the calculated distances between those protons having key NOE correlations around $\mathrm{C}-12$ were ranged from 2.9 to $3.3 \AA$ as shown in Table 3 . Therefore, sinugibberoside 2 was established as $\left(1 S^{*}, 4 S^{*}, 5 S^{*}, 9 R^{*}, 11 S^{*}, 12 S^{*}, 15 R^{*}\right)$ -

Table 3. Calculated distances between selective protons having key NOE correlations of $\mathbf{1}$ and $\mathbf{2}$

\begin{tabular}{lrr}
\hline $\mathrm{H} / \mathrm{H}$ & \multicolumn{2}{c}{ Distance $(\AA)$} \\
\cline { 2 - 3 } & \multicolumn{1}{c}{$\mathbf{1}^{\mathrm{a}}$} & \multicolumn{1}{c}{$\mathbf{2}^{\mathrm{b}}$} \\
\hline $\mathrm{H}_{3}-16 / \mathrm{H}_{3}-18$ & 2.8 & $>4.0$ \\
$\mathrm{H}_{2}-17 / \mathrm{H}_{3}-18$ & $>4.0$ & 3.1 \\
$\mathrm{H}-13 / \mathrm{H}_{3}-18$ & 2.9 & 3.3 \\
$\mathrm{H}-13 / \mathrm{H}-10 \alpha$ & 2.8 & $>4.0$ \\
$\mathrm{H}-13 / \mathrm{H}-10 \beta$ & 3.2 & $>4.0$ \\
$\mathrm{H}-13 / \mathrm{H}-2 \alpha$ & $>4.0$ & 2.9 \\
\hline
\end{tabular}

\footnotetext{
${ }^{a}$ Minimum energy conformers at $228.4 \mathrm{Kcal} / \mathrm{mol}$

b Minimum energy conformers at $232.3 \mathrm{Kcal} / \mathrm{mol}$.
}

4,5-epoxy-12,15-epidioxy-17-acetoxy-xeniaphylla-8(19),13dien-12-ol.

The most polar metabolite, sinugibberoside $\mathrm{C}(\mathbf{3})$, has a molecular formula $\mathrm{C}_{20} \mathrm{H}_{30} \mathrm{O}_{5}$ as indicated from its HRESIMS $\left(\mathrm{m} / \mathrm{z}\right.$ 373.1989, $\left.[\mathrm{M}+\mathrm{Na}]^{+}\right)$and NMR data (Tables 1 and 2). It differs with $\mathbf{1}$ and $\mathbf{2}$ in the absence of an ester moiety as revealed from its IR spectrum and by the lack of the acetate signals from the NMR spectra of $\mathbf{3}$. Comparison of the NMR data of $\mathbf{3}$ with those of $\mathbf{1}$ and $\mathbf{2}$ designated $\mathbf{3}$ as a related 4,5-epoxyxeniaphyllane derivative with the same 3,6-dihydro-1,2-dioxin-3-ol moiety. The substantial upper field shift observed for $\mathrm{H}_{2}-17$ ( $\delta 3.58$ and 3.63) in 3 than those of $\mathbf{1}(\delta 3.98$ and 4.18$)$ and $\mathbf{2}(\delta 4.12$ and 4.27$)$ indicated the presence of a hydroxymethyl at C-15 in $\mathbf{3}$ instead of the acetoxymethyl. However, we have also found that $\mathrm{H}-1(\delta 2.78)$ of $\mathbf{3}$ is resonating in a field quite close to that of $\mathbf{1}(\delta 2.80)$, but in a lower field relative to that of $\mathbf{2}(\delta 2.60)$. This suggested the close vicinity of the peroxide bridge to $\mathrm{H}-1$ in $\mathbf{3}$ as in the case of $\mathbf{1}$, revealing the same $R^{*}$ configuration at $\mathrm{C}-12$ for $\mathbf{3}$. Analysis of NOE correlations displayed in the NOESY spectrum of $\mathbf{3}$ (Fig. 3) has led to similar results as that obtained from the NOESY spectrum of $\mathbf{1}$, including the NOE responses for the olefinic $\mathrm{H}-13$ with both $\mathrm{H}_{2}-10$ and $\mathrm{H}_{3}-18$ and for $\mathrm{H}_{3}-18$ with $\mathrm{H}_{3}-16$. Therefore, the structure of $\mathbf{3}$ was determined as $\left(1 S^{*}, 4 S^{*}, 5 S^{*}, 9 R^{*}, 11 S^{*}, 12 R^{*}, 15 R^{*}\right)-4,5$-epoxy-12,15-epidioxy-xeniaphylla-8(19),13-dien-12,17-diol.

The HRESIMS $\left(\mathrm{m} / \mathrm{z}, 357.2040,[\mathrm{M}+\mathrm{Na}]^{+}\right)$of sinugibberoside D (4) assigned a molecular formula $\mathrm{C}_{20} \mathrm{H}_{30} \mathrm{O}_{4}$, with one oxygen atom less than that found for 3 . The IR $\left(\nu_{\max }\right.$ $\left.3422 \mathrm{~cm}^{-1}\right)$ and ESIMS $\left(\mathrm{m} / \mathrm{z}, 317,\left[\mathrm{M}-\mathrm{H}_{2} \mathrm{O}+\mathrm{H}\right]^{+}\right)$spectra revealed the presence of one hydroxy group in $\mathbf{4}$. Moreover, the NMR data of $\mathbf{4}$ were found to be almost identical with those of 3 except for the replacement of the hydroxymethyl at $\mathrm{C}-15\left(\delta_{\mathrm{H}} 3.58\right.$ and $\left.3.63 ; \delta_{\mathrm{C}} 66.9\right)$ in 3 by a methyl $\left(\delta_{\mathrm{H}} 1.23 ; \delta_{\mathrm{C}} 24.8\right)$ in 4 . Also, the identical chemical shift of $\mathrm{H}-1$ in $\mathbf{4}$ and $\mathbf{3}$ disclosed a similar stereochemistry for the hemiketal carbon at C-12. After the establishment of the gross structure of 4 by the analysis of ${ }^{1} \mathrm{H}-{ }^{1} \mathrm{H}$ COSY and HMBC correlations (Fig. 2), we have found that the NOE interactions revealed by $\mathrm{H}-13$ with both $\mathrm{H}_{2}-10$ and $\mathrm{H}_{3}-18$, and $\mathrm{H}_{3}-16$ with $\mathrm{H}_{3}-18$ also confirmed the $12 R^{*}$ configuration of $\mathbf{4}$, the same as that of $\mathbf{3}$. Therefore, sinugibberoside $\mathrm{D}(\mathbf{4})$ was established as $\left(1 S^{*}, 4 S^{*}, 5 S^{*}, 9 R^{*}, 11 S^{*}, 12 R^{*}\right)-4,5$-epoxy12,15-epidioxy-xeniaphylla-8(19),13-dien-12-ol.

The HRESIMS $\left(\mathrm{m} / \mathrm{z} 357.2041,[\mathrm{M}+\mathrm{Na}]^{+}\right)$of sinugibberoside E (5) combined with NMR data suggested 5 to be an isomer of 4. Also, a hydroxy group was revealed from the IR $\left(\nu_{\max }\right.$ $\left.3422 \mathrm{~cm}^{-1}\right)$ and ESIMS $\left(\mathrm{m} / \mathrm{z}\right.$ 317, $\left.\left[\mathrm{M}-\mathrm{H}_{2} \mathrm{O}+\mathrm{H}\right]^{+}\right)$. Metabolite 5 was found to possess a cyclic peroxyhemiketal moiety from the chemical shift of C-12 $(\delta 99.5, \mathrm{qC})$, as those found in 1-4. The significant lower field shift observed for C-9 $(\Delta \delta+0.5)$ and the upper field shift for C-10 $(\Delta \delta-1.0)$ relative to those in $\mathbf{4}$, a case which is similar by comparison of the corresponding data of $\mathbf{2}$ with those of $\mathbf{1}$, suggested that 5 might be the 12-epimer of $\mathbf{4}$. This was supported by the upper field shift observed for $\mathrm{H}-1$ ( $\delta 2.58)$ of 5 relative to that of $4(\delta 2.78)$. Finally, the NOE interactions observed for $\mathrm{H}-13$ with both $\mathrm{H}-2 \alpha$ and $\mathrm{H}_{3}-18$, as those found in 2 established sinugibberoside E (5) as $\left(1 S^{*}, 4 S^{*}, 5 S^{*}, 9 R^{*}, 11 S^{*}, 12 S^{*}\right)-4,5$ epoxy-12,15-epidioxy-xeniaphylla-8(19),13-dien-12-ol. 
It is noteworthy to mention that sinugibberosides reported here are the first example of marine natural products possessing the rarely found tetrasubstituted peroxyhemiketal moiety, ${ }^{16,17}$ although polyketide-derived metabolites with a trisubstituted cyclic peroxyketal moiety have been isolated from some sponges. ${ }^{14,15}$ The biosynthesis of both $\mathbf{1}$ and $\mathbf{2}$ can be achieved by the nucleophilic attack of $15-\mathrm{OOH}$ at the different sides of the carbonyl group at C-12 of a precursor 7, respectively. Metabolites 3-5 were considered to be biosynthesized by the same approach from the similar precursors with structures related to $\mathbf{1}$.

\section{Experimental}

\subsection{General}

Optical rotations were measured on a Jasco DIP-1000 digital polarimeter. IR spectra were recorded on a Jasco FT-5300 infrared spectrophotometer. The NMR spectra were recorded on a Bruker Avance 300 FT-NMR at $300 \mathrm{MHz}$ for ${ }^{1} \mathrm{H}$ and $75 \mathrm{MHz}$ for ${ }^{13} \mathrm{C}$ or on a Varian Mercury Plus 400 FT-NMR at $400 \mathrm{MHz}$ for ${ }^{1} \mathrm{H}$ and $100 \mathrm{MHz}$ for ${ }^{13} \mathrm{C}$, or on a Varian Unity INOVA 500 FT-NMR at $500 \mathrm{MHz}$ for ${ }^{1} \mathrm{H}$ and $125 \mathrm{MHz}$ for ${ }^{13} \mathrm{C}$, respectively, in $\mathrm{CDCl}_{3}$ using TMS as an internal standard. LRMS data were obtained by EI on a VG Quattro GC-MS spectrometer or by ESI on a BRUKER APEX II mass spectrometer. HRMS were recorded on EI or ESI on a BRUKER APEX II mass spectrometer. Si gel (Merck, 230-400 mesh) was used for column chromatography. Precoated Si gel plates (Merck, Kieselgel $60 \mathrm{~F}_{254}$, $0.2 \mathrm{~mm}$ ) were used for analytical TLC. High-performance liquid chromatography was performed on a Hitachi L-7100 apparatus with Merck Hibar Si-60 column $(250 \times 21 \mathrm{~mm}$, $7 \mu \mathrm{m})$.

\subsection{Organism}

S. gibberosa was collected by hand via scuba from the northern east coast of Taiwan, in June 2004, at a depth of 15$20 \mathrm{~m}$, and stored in a freezer until extraction. A voucher sample was deposited at the Department of Marine Resources, National Sun Yat-Sen University.

\subsection{Extraction and separation}

The bodies of $S$. gibberosa ( $1.3 \mathrm{Kg}$ fresh weight) were minced and extracted exhaustively with EtOAc, and the extract was concentrated under reduced pressure to give a dark brown viscous residue $(15.4 \mathrm{~g})$. The residue was fractionated by open column chromatography on silica gel using $n$-hexane and $n$-hexane-EtOAc mixture of increasing polarity to yield 32 fractions. Fraction 15 eluted with $n$-hexaneEtOAc (5:1) was permeated through a Sephadex LH-20 column $(2 \times 90 \mathrm{~cm})$ in acetone and the lipid-free fraction was subsequently isolated by normal phase HPLC using hexaneacetone (7:1 to $6: 1)$ to give compounds $5(0.7 \mathrm{mg})$ and 4 $(0.5 \mathrm{mg})$. Fraction 20 eluted with $n$-hexane-EtOAc (4:1 to $2: 1)$ was further separated by normal phase HPLC, using $n$-hexane-acetone (4:1 to $3: 1)$ to yield $1(0.5 \mathrm{mg}), 2(0.5 \mathrm{mg})$, and $\mathbf{3}(1.5 \mathrm{mg})$, respectively.

3.3.1. Sinugibberoside A (1). Colorless oil, $[\alpha]_{\mathrm{D}}^{25}+18.3(c$ 0.6, $\mathrm{CHCl}_{3}$ ); IR (neat) $\nu_{\max } 3400,2956,2926,2876,1746$,
$1647,1456,1385,1242,1046 \mathrm{~cm}^{-1}$; for ${ }^{1} \mathrm{H} \mathrm{NMR}\left(\mathrm{CDCl}_{3}\right.$, $500 \mathrm{MHz})$ and ${ }^{13} \mathrm{C} \mathrm{NMR}\left(\mathrm{CDCl}_{3}, 125 \mathrm{MHz}\right)$, see Tables 1 and 2, respectively; EIMS $\mathrm{m} / \mathrm{z} 360\left(0.1,\left[\mathrm{M}-\mathrm{O}_{2}\right]^{+}\right), 344$ $\left(0.1,[\mathrm{M}-3 \mathrm{O}]^{+}\right), 205\left(0.2,\left[\mathrm{M}-\mathrm{C}_{8} \mathrm{H}_{11} \mathrm{O}_{5}\right]^{+}\right), 187(0.3$, $\left.\left[\mathrm{C}_{8} \mathrm{H}_{11} \mathrm{O}_{5}\right]^{+}\right), 175(0.3), 171(0.4), 163(0.5), 159(0.7)$, 147 (1.2), 135 (0.9), 121 (1.7), 111 (1.5), 105 (2.9), 97 (4.0), 93 (2.3), 91 (4.1), 79 (5.1); HRESIMS m/z 415.2093 (calcd for $\mathrm{C}_{22} \mathrm{H}_{32} \mathrm{O}_{6} \mathrm{Na}, 415.2097$ ).

3.3.2. Sinugibberoside $\mathbf{B}$ (2). Colorless oil, $[\alpha]_{\mathrm{D}}^{25}+8.9$ (c 1.7, $\mathrm{CHCl}_{3}$ ); IR (neat) $\nu_{\max } 3400,2957,2937,2877$, 1736, 1640, 1456, 1383, 1242, $1043 \mathrm{~cm}^{-1}$; for ${ }^{1} \mathrm{H}$ NMR $\left(\mathrm{CDCl}_{3}, 300 \mathrm{MHz}\right)$ and ${ }^{13} \mathrm{C} \mathrm{NMR}\left(\mathrm{CDCl}_{3}, 75 \mathrm{MHz}\right)$, see Tables 1 and 2, respectively; FABMS $m / z \quad 393$ (16.6, $[\mathrm{M}+\mathrm{H}]^{+}$); HRESIMS $\mathrm{m} / \mathrm{z} 415.2093$ (calcd for $\mathrm{C}_{22} \mathrm{H}_{32} \mathrm{O}_{6} \mathrm{Na}$, 415.2097).

3.3.3. Sinugibberoside $\mathbf{C}$ (3). Colorless oil, $[\alpha]_{\mathrm{D}}^{25}+33.3(c$ $0.2, \mathrm{CHCl}_{3}$ ); IR (neat) $\nu_{\max } 3400,2930,2880,1647,1541$, 1456, 1387, $1049 \mathrm{~cm}^{-1}$; for ${ }^{1} \mathrm{H} \mathrm{NMR}\left(\mathrm{CDCl}_{3}, 400 \mathrm{MHz}\right)$ and ${ }^{13} \mathrm{C} \mathrm{NMR}\left(\mathrm{CDCl}_{3}, 100 \mathrm{MHz}\right)$, see Tables 1 and 2, respectively; ESIMS $\mathrm{m} / \mathrm{z} 373\left(100,[\mathrm{M}+\mathrm{Na}]^{+}\right), 333(3$, $\left.\left[\mathrm{M}-\mathrm{H}_{2} \mathrm{O}+\mathrm{H}\right]^{+}\right), 285\left(12,\left[\mathrm{M}-\mathrm{H}_{2} \mathrm{O}-3 \mathrm{O}+\mathrm{H}\right]^{+}\right), 267 \quad(2$, $\left.\left[\mathrm{M}-2 \mathrm{H}_{2} \mathrm{O}-3 \mathrm{O}+\mathrm{H}\right]^{+}\right), 205\left(6, \quad\left[\mathrm{M}-\mathrm{C}_{6} \mathrm{H}_{9} \mathrm{O}_{4}\right]^{+}\right)$; ESIMS $m / z 350\left(0.1,\left[\mathrm{M}^{+}\right), 318\left(0.5,[\mathrm{M}-2 \mathrm{O}]^{+}\right), 316(0.1,[\mathrm{M}-\right.$ $\left.\left.\mathrm{H}_{2} \mathrm{O}-\mathrm{O}\right]^{+}\right), 302\left(0.2,[\mathrm{M}-3 \mathrm{O}]^{+}\right), 205\left(1.8,\left[\mathrm{M}-\mathrm{C}_{6} \mathrm{H}_{9} \mathrm{O}_{4}\right]^{+}\right)$, 187 (1.4), 175 (1.2), 164 (2.3), 163 (3.4), 159 (2.9), 149 (3.5), 148 (6.0), 135 (5.1), 121 (10.6), 111 (5.9), 105 (18.0), 97 (29.4), 93 (14.3), 91 (25.7), 79 (30.5); HRESIMS $m / z 373.1989$ (calcd for $\mathrm{C}_{20} \mathrm{H}_{30} \mathrm{O}_{5} \mathrm{Na}, 373.1991$ ).

3.3.4. Sinugibberoside $\mathrm{D}$ (4). Colorless oil, $[\alpha]_{\mathrm{D}}^{25}+47.2(c$ $0.2, \mathrm{CHCl}_{3}$ ); IR (neat) $\nu_{\max } 3422,2924,2874,1647,1512$, 1456, $1396,1051 \mathrm{~cm}^{-1}$; for ${ }^{1} \mathrm{H} \mathrm{NMR}\left(\mathrm{CDCl}_{3}, 400 \mathrm{MHz}\right)$ and ${ }^{13} \mathrm{C} \mathrm{NMR}\left(\mathrm{CDCl}_{3}, 100 \mathrm{MHz}\right)$, see Tables 1 and 2, respectively; ESIMS $m / z \quad 357 \quad\left(100, \quad[\mathrm{M}+\mathrm{Na}]^{+}\right), \quad 341$ $\left(30, \quad[\mathrm{M}-\mathrm{O}+\mathrm{Na}]^{+}\right), \quad 335 \quad\left(9, \quad[\mathrm{M}+\mathrm{H}]^{+}\right), \quad 317 \quad(57$, $\left.\left[\mathrm{M}-\mathrm{H}_{2} \mathrm{O}+\mathrm{H}\right]^{+}\right), 301\left(13,\left[\mathrm{M}-\mathrm{H}_{2} \mathrm{O}-\mathrm{O}+\mathrm{H}\right]^{+}\right), 285(10$, $\left.\left[\mathrm{M}-\mathrm{H}_{2} \mathrm{O}-2 \mathrm{O}+\mathrm{H}\right]^{+}\right)$; EIMS m/z $302\left(0.2,[\mathrm{M}-2 \mathrm{O}]^{+}\right), 205$ $\left(2.3,\left[\mathrm{M}-\mathrm{C}_{6} \mathrm{H}_{9} \mathrm{O}_{3}\right]^{+}\right), 187$ (6.1), 173 (5.2), 164 (6.2), 161 (10.9), 149 (23.1), 148 (14.8), 138 (25.9), 122 (38.1), 105 (38.3), 95 (61.4), 91 (68.5), 79 (66.5); HRESIMS $\mathrm{m} / \mathrm{z}$ 357.2040 (calcd for $\mathrm{C}_{20} \mathrm{H}_{30} \mathrm{O}_{4} \mathrm{Na}, 357.2042$ ).

3.3.5. Sinugibberoside E (5). Colorless oil, $[\alpha]_{\mathrm{D}}^{25}+36.1(c$ $0.4, \mathrm{CHCl}_{3}$ ); IR (neat) $\nu_{\max } 3422,2924,2874,1647,1541$, 1456, $1397,1049 \mathrm{~cm}^{-1}$; for ${ }^{1} \mathrm{H} \mathrm{NMR}\left(\mathrm{CDCl}_{3}, 400 \mathrm{MHz}\right)$ and ${ }^{13} \mathrm{C} \mathrm{NMR}\left(\mathrm{CDCl}_{3}, 100 \mathrm{MHz}\right)$, see Tables 1 and 2, respectively; ESIMS m/z $357\left(100,[\mathrm{M}+\mathrm{Na}]^{+}\right), 341(74$, $\left.[\mathrm{M}-\mathrm{O}+\mathrm{Na}]^{+}\right), 317\left(23,\left[\mathrm{M}-\mathrm{H}_{2} \mathrm{O}+\mathrm{H}\right]^{+}\right) ;$EIMS $\mathrm{m} / \mathrm{z} 302$ $\left(1.5,[\mathrm{M}-2 \mathrm{O}]^{+}\right), 205\left(3.3,\left[\mathrm{M}-\mathrm{C}_{6} \mathrm{H}_{9} \mathrm{O}_{3}\right]^{+}\right), 187$ (8.2), 173 (5.3), 164 (8.4), 163 (12.0), 159 (17.4), 149 (16.9), 148 (13.2), 138 (24.9), 137 (26.2), 123 (58.4), 109 (37.2), 105 (49.2), 95 (54.9), 91 (62.3), 79 (77.7); HRESIMS $\mathrm{m} / \mathrm{z}$ 357.2041 (calcd for $\mathrm{C}_{20} \mathrm{H}_{30} \mathrm{O}_{4} \mathrm{Na}, 357.2042$ ).

3.3.6. Molecular mechanics' calculations. The minimum energy conformation of $\mathbf{1}$ and $\mathbf{2}$ was determined using the MSI Insight II/DISCOVER version 95 molecular modeling package incorporating an empirical force field, the consistent valence force field $(\mathrm{CVFF}),{ }^{19}$ on a Silicon Graphics IRIS Indigo XS24/R4000 workstation. Molecular mechanics was utilized to investigate the minimization, 
and minimum energy was calculated by a conjugate gradient method until the maximum derivative was less than $0.001 \mathrm{Kcal} / \mathrm{mol} \AA$. The conformers shown in Figure 4 are the lowest energy conformation for $\mathbf{1}$ and $\mathbf{2}$.

\section{Acknowledgements}

This work was supported by a grant from the National Science Council of the Republic of China (Contract No. NSC-90-2323-B-110-003) awarded to J.-H. Sheu.

\section{References and notes}

1. Blunt, J. W.; Copp, B. R.; Munro, M. H. G.; Northcote, P. T.; Prinsep, M. R. Nat. Prod. Rep. 2006, 23, 26-78 and previous reports in this series.

2. Tseng, Y.-J.; Ahmed, A. F.; Dai, C.-F.; Chiang, M. Y.; Sheu, J.-H. Org. Lett. 2005, 7, 3813-3816 and references cited therein.

3. Ahmed, A. F.; Su, J.-H.; Shiue, R.-T.; Pan, X.-J.; Dai, C.-F.; Kuo, Y.-H.; Sheu, J.-H. J. Nat. Prod. 2004, 67, 592-597.

4. Sung, P.-J.; Hu, W.-P.; Wu, S.-L.; Fang, L.-S.; Wang, J.-J.; Sheu, J.-H. Tetrahedron 2004, 60, 8975-8979.

5. Sheu, J.-H.; Chao, C.-H.; Wang, G. H.; Hung, K.-C.; Duh, C.-Y.; Chiang, M.-Y.; Wu, Y.-C.; Wu, C. C. Tetrahedron Lett. 2004, 45, 6413-6416.
6. Ahmed, A. F.; Shiue, R.-T.; Wang, G.-H.; Dai, C.-F.; Kuo, Y.-H.; Sheu, J.-H. Tetrahedron 2003, 59, 7337-7344.

7. Wang, G.-H.; Sheu, J.-H.; Duh, C. Y.; Chiang, M. Y. J. Nat. Prod. 2002, 65, 1475-1478.

8. Sheu, J.-H.; Wang, G.-H.; Sung, P. J.; Duh, C.-Y.; Chiang, M. Y. Tetrahedron 2001, 57, 7639-7648.

9. Ahmed, A. F.; Dai, C.-F.; Kuo, Y.-H.; Sheu, J.-H. Steroids 2003, 68, 377-381.

10. Ahmed, A. F.; Kuo, Y.-H.; Dai, C.-F.; Sheu, J.-H. J. Nat. Prod. 2005, 68, 1208-1212.

11. Ahond, A.; Bowden, B. F.; Coll, J. C.; Fourneron, J.-D.; Mitchell, S. J. Aust. J. Chem. 1981, 34, 2657-2664.

12. Groweiss, A.; Kashman, Y. Tetrahedron 1983, 39, 3385-3396 and references cited therein.

13. Snider, B. B.; Shi, Z. J. Am. Chem. Soc. 1992, 114, 1790-1800.

14. Wells, J. R. Tetrahedron Lett. 1976, 17, 2637-2638.

15. Quiñoā, E.; Kho, E.; Manes, L. V.; Grews, P. J. Org. Chem. 1986, 51, 4260-4264.

16. Appendino, G.; Gariboldi, P.; Nano, G. M.; Tétényi, P. Phytochemistry 1984, 23, 2545-2552.

17. Marco, J. A.; Sanz-Cervera, J. F.; García-Lliso, V.; Guara, M.; Vallès-Xirau, J. Phytochemistry 1997, 45, 751-754.

18. Thebtaranonth, C.; Thebtaranonth, Y.; Wanauppathamkul, S.; Yuthavong, Y. Phytochemistry 1995, 40, 125-128.

19. MSI Insight II/DISCOVER (version 95.0/2.97) is a molecular modeling software package of MSI Technologies Inc., Barnes Canyon Road, San Diego, CA 92121. 